\title{
DİN VE DEĞER İLİSKIISİ: İSRAFA KARŞI FARKINDALIK ÜZERİNE UYGULAMALI BİR ARAŞTIRMA
}

\author{
Fatih Çınar
}

Dr. Öğr. Üyesi, Süleyman Demirel Üniversitesi, İlahiyat Fakültesi, Din Eğitimi Anabilim Dalı Asst. Prof. Süleyman Demirel University, Faculty of Theology, Department of Religious Education Isparta, Turkey

fatihcinar@sdu.edu.tr orcid.org / 0000-0002-0216-3714

Doi: $10.14395 /$ hititilahiyat. 443570

Öz

Din-değer ilişkisinin temel alındığı bu araştırmada Din Kültürü ve Ahlak Bilgisi (DKAB) dersinin öğrencilerin israf konusundaki dini yaklaşım (bilgi ve tutum) ve israfa karşı farkındalık düzeyleri üzerindeki etkisi incelenmiştir. Araştırmada deneysel çalışma yönteminin tek gruplu ön-test sontest deneysel deseni kullanıımıştır. Araştırmanın örneklem grubunu 6. sınıfa devam eden 59 öğrenci oluşturmaktadır. Araştırmada katılımcılara 6 hafta süre ile israf konusunda DKAB dersleri ile bütünleştirilmiş proje tabanlı ve aktif öğrenme merkezli etkinlikleri uygulanmıştır. Araştırma verileri araştırmacı tarafından geliştirilen Dini Bilgi ve Tutum Ölçeği (DBTÖ) ile İsrafa Karşı Farkındalık Ölçeği (IKKFÖ) ile toplanmıştır. Verilerin analizinde bağımlı gruplar t-testi, bağımsız gruplar t testi, tek yönlü varyans analizi ve pearson korelasyon testleri kullanılmıştır. Araştırma sonucunda; öğrencilerin israf konusundaki dini bilgi ve tutumları arttıkça israfa karşı farkındalık düzeylerinin de artıı̆ı; proje tabanlı ve aktif öğrenme merkezli gerçekleştirilen DKAB dersinin öğrencilerin DBTÖ ve İKFÖ ön test- son test puanlarında istatistiksel olarak anlamlı farklılaşmaya neden olduğu tespit edilmiştir. Sonuçlar dinin, değerler üzerindeki etkisini uygulamalı olarak ortaya koyması açısından oldukça önemlidir.

Anahtar Kelimeler: Din Eğitimi, Değerler Eğitimi, İsraf, Ölçek, Din Kültürü ve Ahlak Bilgisi

\section{Correlation between Religion and Value: an Experimental Research on the Awareness on Waste}

\begin{abstract}
This study aims to investigate the effect of Religious Education and Moral Information (RCME) courses on levels of religious knowledge, attitude about waste and awareness against wastage; It also examines the correlation between religiosity and value. In this study was used singlegroup pretest-posttest experimental design from preexperimental methods. The sample of study was composed of 59 pupils from sixth grade students who studies in secondary schools. Project-based and active learning-centered activities related waste and integrated with RCME courses have been implemented to students during 6 weeks. Research data were collected "Religious Knowledge and Attitude Scale" and "Awareness on Waste Scale"which developed by the researcher. Paired samples t-test, independent sample $t$ test, one-way analysis of variance, pearson correlation test and was used in the analysis of data in the .05 significance level. The result of the study showed that while a positive correlation was found between Religious Knowledge and Attitude and Awareness on Waste of students. The results also indicated that RCME courses have positive effect on Religious Knowledge and Attitude and Awareness on Waste of students.
\end{abstract}

Keywords: Religious Education, Values Education, Waste, Scale, Religious Education and Moral Information 


\section{Giriş}

Eğitim sistemleri oluşturulurken dayandıkları bir eğitim felsefesi bulunmaktadır. Bu felsefe toplumun yetiştirmek istediği insan tipini ve oluşturulmak istenen toplum modelini ortaya koymaktadır. Bu nedenle eğitim süreci içerisinde yapılan her türlü plan ve etkinlikler belirli bir amacı gerçekleştirmeye katkı sağlamaktadır. ${ }^{1}$ Oluşturulmak istenen eğitim sisteminin gerek toplumdaki gerekse dünyadaki değişmelerden bağımsız olarak düşünülmesi mümkün değildir. ${ }^{2}$ Nitekim son dönemlere kadar "pozitivist, sadece olgusal bilgi ve bilim anlayışının etkisinde şekillenen modern eğitim sisteminin, öğrencilerin iç dünyalarını besleyen ahlaki ve manevi değerler hususunda, sessiz, hatta bazen dışlayıcı olmayı tercih eden yaklaşımından ${ }^{3}$ bugün vazgeçmesi bu etkileşimin gereğidir. Çünkü modern eğitim aldatmacasıyla ilerleme olarak kabul edilen teknolojinin ve pozitivist anlayışın sonuçları, toplumlarda insan hafızasının alamayacağı yıkım ve tahribatlara yol açmış ve mevcut anlayışın insanlığın problemlerini çözmede yetersiz kaldığını ve eğitimde yeni paradigmalara ihtiyaç olduğunu ortaya koymuştur. ${ }^{4}$ Her paradigma belli bir sorunsala bir açıklama veya çözüm getirmek savı ile ortaya çıkmaktadır. ${ }^{5}$ Modern toplumun sosyal ve ahlaki değerler konusunda karşı karşıya kaldığı ciddi sorunlar ve gerilim alanları sorunsalı $\mathrm{da},{ }^{6}$ maneviyata yönelik bir eğitimi, pozitivist bilginin dışında bırakan dışlayıcı yaklaşımın" yerine "evrensel insani ve ahlaki değerlerden beslenen olumlu iyi bir karakter yapısı geliştirmeyi okul eğitiminin bir parçası olarak gören bakış açısın getirmiştir." Bu paradigma değişikliğinin eğitimde getirdiği yeni anlayış ve uygulamalardan biri de Değerler Eğitimidir. ${ }^{8}$

1 Mehmet Şişman, Eğitim Bilimine Giriş, (Ankara: PegemA Yayıncılık, 2007), 19. Yüksel Özden, Eğitimde Yeni Değerler, (Ankara: PegemA Yayıncılık, 2005), 8.

3 Seyfi Kenan, "Modern Eğitimde Kaybolan Nokta: Değerler Eğitimi”, Kuram Ve Uygulamada Eğitim Bilimleri 9/1 (2009): 263.

4 Mustafa Köylü, Teoriden Pratiğe Değerler Eğitimi, (Ankara: Nobel Yayıncılık, 2016), 10.

5 Yüksel Özden, Ĕ̆itimde Yeni Değerler, s.8.

6 Seyfi Kenan, “Modern Eğitimde Kaybolan Nokta: Değerler Eğitimi”, 261.

7 Bu yaklaşıma göre "bilimin dişında tutulan değerler, teorik tartışmalar ve izah etmeler açısından konu edilebilir ancak insan yaşamına yön veren ahlaki değerler gözle görülemeyen ölçülemeyen nitelikte olduğundan dolayı dışta bırakılmalıdır." (Kenan, "Modern Eğitimde Kaybolan Nokta: Değerler Eğitimi”, 263; Köylü, Teoriden Pratiğe Değerler Eğitimi, 10.)

8 Hayati Hökelekli, "Modern Eğitimde Yeni Bir Paradigma: Değerler Eğitimi”, Eğitime Bakış 18 (2010): 5 
Ülkemizde de gerek yaygın (aile) gerekse örgün eğitimde değerlerin planlı veya örtük şekilde çocuklara aktarılması toplumsal bir sorumluluk bilincinde ele alınmış ve değerlerin aktarılıp aktarılmayacağı, içeriğinin ne olacağı gibi konuların tartışılmasından daha çok; değerlerin nasıl, ne zaman ve hangi yöntemlerle aktarılacağı sorusuna odaklanılmıştır. ${ }^{9}$ Bu sorumluluktan hareketle Milli Eğitim Bakanlığı da yok olmaya yüz tutmuş değerlerimizi korumak ve çocuklarımıza yaşanılabilir bir dünya bırakmak amacıyla; birçok dersin öğretim programında -önceden genel hedefler içinde ifade ettiği- değerlere, programın değerleri başlığı altında yer vererek katkı sağlamıştır. Çünkü öğrencinin öğrenme süreci öncesinde edindiği kişisel bilgi, görüş, inanç ve değerlerin öğrenmeyi etkileyeceği muhakkaktır. ${ }^{10}$ Bununla birlikte eğitimde duygusal boyutun ihmal edilmesi, bireyin doğuştan sahip olduğu yeteneklerini keşfedememesi ve geliştirememesi gibi bir sonucu doğuracaktır. Eğitimin en temel amacı bireyin kişilik gelişimine katkıda bulunmaktır. Değerlerden arındırılmış sadece bilişsel bilgi aktarımına dayalı bir eğitim, bireyin kişilik oluşumuna gerçekleştiremediği gibi; bilgiye sahip olan fakat bu bilgiyi içselleştiremeyen bir neslin oluşmasına neden olacak; bu bakış açısı ile yetişmiş bir toplum da sadece bilgiyi üreten, fakat ürettiği bilgiyi insanlık yararına kullanılması yönünde bir değer yargısına sahip olmayan toplum olacaktır. Oysa insanın dolayısıyla içinde bulunduğu toplumun mutluluğunun vazgeçilmez temel unsuru, sahip olduğu değerler sistemi ve bu kültürel kodların içselleştirilmesi ile yakından ilişkilidir. ${ }^{11}$

Değerlerle ilişkisi olan temel konulardan birisi de ahlaktır. Ahlak, bir yönü ile değer-eylem bileşkesinde, bir yönüyle de değer-din bileşkesinde yer alan olgudur. Yani bir ayağı salt bir değer veya soyutlanmış bir eylem olmamakla birlikte değerlerde iken diğer ayağı eylemdedir. Eylemselliğin ötesinde ahlakın önemli bir özelliği, bir şeyin iyi ya da kötü oluşuna dair bir hüküm koyması; yani yargılaşmış değerler olmasıdır. Bütün değerlerde olduğu gibi ahlâkın da önemli bir kaynağı aşkınlıktır, dindir. Özellikle İlahi kaynaklı dinler, İnanırları için önemli ahlak ilkeleri koymaktadır. Din, değerlerin oluşma, sürdürülme ve insan hayatı üzerinde etkinlik kazandırılması

9 Yurdagül Mehmedoğlu, Ahlaki ve Dini Gelişim \& Çocuğum Değerlerimizi Öğreniyor, (İstanbul: Morpa Kültür Yayınları 7 ,2004.

10 Mehmet Zeki Aydın - Şebnem Akyol Gürler, Okulda Değerler Eğitimi Yöntemler Etkinlikler Kaynaklar, (Ankara: Nobel Yayınları 2012), 52; Oktay Akbaş, “Değer Eğitimi Akımlarına Genel Bir Bakış", Değerler Eğitimi Dergisi, 6/ 16 (Aralık 2008): 10.

11 Kadir Ulusoy - Bülent Dilmaç, Değerler Ĕ̆itimi, (Ankara: PegemA Akademi Yayıncılık 2014), 52-53. 
sürecinde önemli bir etkiye sahiptir. Çünkü din, değerlerle olan ilişkisinde sadece dini değerlerin bireyde etkin olmasını sağlamaz. Aksine doğrudan dini olmayan değerler için de bir hiyerarşi oluşturur, onlara aşkın kökenler sağlar ve işlevselliğini arttırır. Çünkü bireyler için aşkın değerlerin vicdani yaptırımları daha ağır basmakta ve çoğu zaman içkin değerlerden de daha etkili olabilmektedir. ${ }^{12}$ Örneğin "toplumumuzda, vatan, millet sevgisi, şehitlik, gazilik, insanları sevme sayma, sorumluluk, sabır, paylaşma, yardımlaşma, şefkat, merhamet, büyüklere sayg, ilme ve sanata sevgi, aileye saygı, aile bütünlüğ̈̈nü koruma, insan ilişkileri gibi değerler üstün değerler arasında kabul edilmektedir. Bu değerlerin kökleri araştırıldığında, her birinin altında az veya çok Allah'a ve dine olan inançların yattı̆̆ın görmek mümkün olacaktır. Örneğin, vatan sevgisi değerinin oluşmasında, İslam'ın getirdiği şehitlik ve gazilik düşüncesinin, çok büyük rolü ve yeri vardır. Aynı şekilde, vakıfların kurulmasında ve yardımlaşmada, "Hayırda yarışını." ayetinin ve öldükten sonra amel defterinin kapanmaması inancinın etkisi büyüktür. İnsani değerler ya da temel değerler dediğimiz bu vb. değerler, insanın en iyi tarafin ortaya çıkarmayı ve onun kişiliğini bütünüyle geliştirerek, insani mükemmelliğe erişmesini sağlamayı amaçlamaktadır."13

Değerler ilişkisinde ana kural, basit değerlerin yüksek değerler tarafından gözetim ve denetim altında tutularak, işlevselliğinin arttırılmasıdır. Çünkü değer yükseldikçe, değer kişisel olmaktan çıkar, geneli kapsayan genel geçer bir kurala dönüşür. Bu nedenle değerlerin kaynağında sadece toplumların etkileşimini temel almak ve oluşturulacak değer eğitiminde sadece bu öngörüden hareket etmek, bireyin sahip olduğu inançların, onun duygu, düşünce ve tutumlarının oluşmasında önemli bir etkiye sahip olduğu gerçeğinin de göz ardı edilmesine neden olacaktır. ${ }^{14}$ Çünkü kültürlerin alt yapısı olan din ve onun öğeleri konusunda çocukları bilgilendirmemek, temel ve evrensel değerleri kazanmaları konusunda da onları dayanaksız ve bilgisiz bırakmak demektir. ${ }^{15}$ Örgün eğitimde de aşkın değerlerin içkin değerlere ilişkisinden hareketle; Din Kültürü ve Ahlak Bilgisi ${ }^{16}$ derslerinde, değer merkezli bir eğitime, DKAB öğretim programının öncelikleri arasında yer verilmiştir. Programda değerlerin niçin öğrenilmesi gerektiği ile ilgili Evrensel temelde

12 Mustafa Aydın, “Değerler, İşlevleri ve Ahlak”, Eğitime Bakış, 7/19 (2011): 43.

13 Mehmet Zeki Aydın, “Okulda Çalışan Herkesin Görevi Olarak Değerler Eğitimi”, erişim 1 Nisan 2017. http://www.okuloncesi.net/upload/dosyalar/20111113/2300/2010-22.doc

14 Aydın, "Değerler, İşlevleri ve Ahlak", 43.

15 Mehmedoğlu, Ahlaki ve Dini Gelişim \& Çocuğum Değerlerimizi Öğreniyor, 18.

16 Çalışmanın bundan sonraki kısmında DKAB şeklinde kısaltılarak kullanılacaktır. 
vurgu yapılmış ve kazanımlar değerlerle ilişkilendirilmiştir. Genel amaçlarda değerler ilgili hedefler konmuş, öğrenme alanlarında değerler ile ilgili ünitelere yer verilmiş ve öğrencilerin içselleştirilmesi ön görülen birçok değer, liste halinde verilmiştir. Din ve ahlak konularını öğrenmenin aktif bir süreç olması gerektiği ifade edilmiş, değer öğretiminde dikkat edilmesi gereken hususlar ve öğrenme sürecinde kullanılabilecek yaklaşım, yöntem ve teknikler ile ilgili bilgilere yer verilmiştir. ${ }^{17}$

Literatürde demokratik vatandaşlık ve din eğitimi arasındaki ilişki literatüre ve $D K A B$ öğretim programına dayandırılarak incelenmiş; DKAB dersi öğretim programı ve ders kitapları adalet, ${ }^{18}$ hoşgörü, ${ }^{19}$ bilimsellik ${ }^{20}$ merhamet $^{21}$ ve çevre duyarlılığ ${ }^{22}$ değerleri çerçevesinde araştırılmıştır. ${ }^{23}$ Literatürde genelde örgün din eğitiminin (DKAB derslerinin), bireylerde değerlerin içselleşmesine etkisine-ilişkisine yönelik nitel çok fazla araştırma bulunurken uygulamaya yönelik çok fazla araştırma bulunmadığı gözlenmiştir. Bu durum araştırmanın gerekliliğini ortaya koyan nedenlerden biri olmuştur. Bu gereklilikten yola çıkılarak araştırmada da teorideki din ve değer arasındaki ilişkisini uygulamada ortaya koyabilmek amacıyla örgün eğitimde DKAB dersleri ve israf ${ }^{24}$ konusu ele alınmıştır.

17 Fatih Çınar, Din Öğretiminde Değerler Eğitimi, Değerler Eğitimi, ed. Mevlüt Gündüz, (Ankara: Maya Akademi 2015).

18 Ahmet Çakmak, İlköğretim Din Kültürü ve Ahlak Bilgisi Derslerinde Adalet Değerinin Öğretimi, (Yüksek Lisans Tezi, Atatürk Üniversitesi, 2013).

19 Mustafa Fatih Ay, İlköğretim Din Kültürü ve Ahlak Bilgisi Derslerinde Hoşgörü Değerinin Öğretim, (Yüksek Lisans Tezi, Atatürk Üniversitesi, 2013).

20 Ali Gücen, İlköğretim Din Kültürü ve Ahlak Bilgisi Derslerinde Bilimsellik Değerinin Öğretim, (Yüksek Lisans Tezi, Atatürk Üniversitesi, 2014).

21 Fatih Gör, İlköğretim Din Kültürü ve Ahlak Bilgisi Öğretim Programinda Merhamet Değeri, (Yüksek Lisans Tezi, Atatürk Üniversitesi, 2013).

22 Osman Abalı, İlk ve Ortaöğretim Din Kültürü ve Ahlak Bilgisi Derslerinde Çevre Ĕ̆itimi, (Yüksek Lisans Tezi, Çukurova Üniversitesi, 2014).

23 Recep Kaymakcan - Haşan Meydan, "Demokratik Vatandaşlık ve Din Öğretimi: Yeni Yaklaşımlar ve Türkiye'de DKAB Dersleri Bağlamında Bir Değerlendirme", i̇.Ü. İlahiyat Fakültesi Dergisi 1/1 (2010): 29-53; Bayramali Nazıroğlu, “İlköğretim Din Kültürü ve Ahlak Bilgisi Dersi Öğretim Programında Vatandaşlık Eğitimi” Din Bilimleri Akademik Araştırma Dergisi 11/2 (2011): 73-95.

24 "israf, "haddi aşma, hata, cehalet, gaflet" gibi anlamlara gelen seref kökünden türetilmiş olup genel olarak inanç, söz ve davranışta dinin, akıl veya örfün uygun gördüğü ölçülerin dışına çıkmayı, özellikle mal veya imkânları meşrû olmayan amaçlar için saçıp savurmayı ifade etmektedir. Bk. Saffet Sancaklı, "Hadisler Çerçevesinde İsraf Olgusunun Analizi”, İ.Ü. İlahiyat Fakültesi Dergisi 4/1 (2013): 47 
İçinde bulunduğumuz bilgi çağının temel problemlerinden biri olan tüketim çılgınlığının sonu, toplumların da çöküşü olacaktır. Bu nedenle israf toplumsal bir sorundur ve toplumsal bir sorunun-problemin din olmadan çözümü oldukça zordur. Dinin temel gayesi erdemli, ahlaklı bireyler yetiştirebilmektir. İsraf yapmaktan kaçınmayan birinin bireysel ve toplumsal açıdan erdemli olması mümkün değildir. Çünkü israf kültürü, bireyin kendini düşünen, nefsine yenik düşmüş ve sadece tüketmeye odaklanmış biri olmasını sağlayacaktır. İsraf denilince akla sadece yiyecek-içecek, mal mülk veya maddi imkanlar akla gelmemeli; maddi manevi her türlü nimetin yaratılış gayesine uygun şekilde kullanılmaması, lüzumsuz yere harcanması, nimetin kıymetinin bilinmemesi gelmelidir. Bu açıdan israf, sadece doğal kaynakların aşırı tüketilmesi değil, nimeti veren Yaratıcı'ya Allah'a şükretmek yerine yapılan bir saygısızlıktır. İslam israf yerine her türlü işte ve davranışta dengeli olma anlamına gelen iktisat kavramını önermiştir. Çünkü İslam dininde ifrat ve tefrit değil itidalli olma vardır. İnsan hayatının denge üzerine kurulmasını isteyen İslam'a göre inançta, sözde fiilde, davranışta, sosyal ilişkilerde itidalli olma temel esastır. Nitekim bireyin doğası da itidalli olmaya uygun yaratılmıştır. Bu nedenle maddi manevi konularda itidalli davranmak inancın bir gereğidir. İsrafı önlemek ve tasarruf sahibi ve erdemli bir birey yetiştirme eğitimde temel amaçlar arasında olmalı ve israftan uzak durmanın bir ibadet olduğu bilinci verilecek din eğitimi ile bireylerin zihnine kodlanmalıdır. ${ }^{25}$ Böylece aşkın değerlerin içkin değerler üzerindeki etkisinden pozitif yönde yararlanılmış ve çocuklarda israfa karşı farkındalık ile birlikte, sorumluluk, özdenetim, kanaatkârlık gibi değerlerin içselleşmesine katkıda bulunulmuş olacaktır.

Buradan hareketle bu çalışmada DKAB dersinin, öğrencilerin israf konusunda dini bilgi, tutum ve israfa karşı farkındalık düzeyleri üzerindeki etkisi araştırılmış ve bu amaç doğrultusunda aşağıdaki araştırma sorularına cevap aranmışır.

1. "Dini Bilgi ve Tutum" ölçeği (DBTÖ) ve boyutları ile "İsrafa Karşı Farkındalık" ölçeği(İKFÖ) ve boyutları arasında anlamlı bir ilişki var mıdır?

2. Öğrencilerin DBTÖ ve boyutlarına yönelik ön test- son test puanları arasında istatistiksel olarak anlamlı fark var mıdır?

25 Saffet Sancaklı, "Hadisler Çerçevesinde İsraf Olgusunun Analizi", 47-79.

Hitit Üniversitesi İlahiyat Fakültesi Dergisi, 2018/1, c. 17, sayı: 33 
3. Öğrencilerin İKFÖ ve boyutlarına yönelik ön test- son test puanları arasında istatistiksel olarak anlamlı fark var mıdır?

4. Öğrencilerin

a. DBTÖ ön test- son test puanlarında cinsiyet değişkenine göre anlamlı bir farklılık var midır?

b. İKFÖ ön test- son test puanlarında cinsiyet değişkenine göre anlamlı bir farklılık var midır?

c. DBTÖ ön test- son test puanlarında israf türü değişkenine göre anlamlı bir farklılık var mıdır?

d. İKFÖ ön test- son test puanlarında israf türü değişkenine göre anlamlı bir farklılık var midır?

\section{Yöntem}

\subsection{Araştırmanın Deseni}

DKAB dersinin öğrencilerin israf konusunda dini bilgi, tutum ve israfa karşı farkındalık düzeyleri üzerindeki etkisi araştırmayı amaçlayan bu çalışmada, nicel araştırma yaklaşımlarından "deneysel çalışma" yönteminin tek gruplu ön test -son test deneysel deseni kullanılmıştır.

\section{2. Örneklem Grubu}

Araştırmada örneklem grubun seçiminde uygun amaçlı örneklem (Convenience purposeful sampling) kullanılmıştır ve araştırma, evrenden seçilen örneklem üzerinde gerçekleştirilmiştir. Çalışmanın evrenini Türkiye'de 2015-2016 eğitim-öğretim yılında 6.sınıfta öğrenim gören tüm öğrenciler oluşturmaktadır. Araştırmanın örneklem grubunu ise Isparta il merkezinde bir ortaokulda öğrenim gören 59 gönüllü 6. sınıf öğrencisi oluşturmuştur.

Tablo 1: Örneklem grubunun cinsiyet dağlımı

\begin{tabular}{ccc}
\hline & Frekans & $\%$ \\
\hline K1z & 29 & 49,2 \\
Erkek & 30 & 50,8 \\
Toplam & 59 & 100 \\
\hline
\end{tabular}

Tablo 1'de de görüldüğü üzere araştırma grubunun \%51'i kız; \%49'u erkektir. 
Tablo 2: Örneklem grubuna göre en çok yapılan israf türü

\begin{tabular}{lcc}
\hline & Frekans & $\%$ \\
\hline Elektrik & 16 & 27,1 \\
Zaman & 26 & 44,1 \\
Kağıt & 3 & 5,1 \\
Para & 8 & 13,6 \\
Su & 6 & 10,2 \\
Total & 59 & 100 \\
\hline
\end{tabular}

Örneklem grubuna, günümüzde en fazla hangi israfın yapıldığını düşündükleri sorusu yöneltilmiş ve katılımcılar en çok zaman ve elektrik israfının yapıldığını ifade etmişlerdir.

\subsection{Veri Toplama Araçları}

Araştırmada 3 veri toplama aracı kullanılmıştır. Öğrencilere yönelik "kişisel bilgi formu", "dini bilgi ve tutum" ölçeği ve "israfa karşı farkındalık" ölçekleri kullanılmıştır. Kişisel bilgi formu öğrencilerin cinsiyetlerini ve en çok yaptıklarını düşündükleri israf türünü ortaya koyan 2 sorudan oluşmaktadır.

\subsubsection{Dini Bilgi ve Tutum Ölçeği (DBTÖ)}

Araştırmanın yapılacağı ve ölçeklerin uygulanacağı kitle dikkate alınarak 6. Sınıfta öğrenim gören 20 öğrenciye DKAB dersinde "çevrelerinde en çok karşılaştıkları israf türleri, toplumsal boyutları ve günlük hayatlarında israfı önlemek için neler yapabilecekleri, dini bilgi ve tutumların israfı önlemede etkisi" ile ilgili kompozisyon yazdırılmıştır. Daha sonra bu veriler analiz edilmiş ve oluşturulacak iki ölçek için tutum soruları oluşturulmuştur.

Elde edilen veriler ile birlikte ilgili literatür taranmış ve çocukların israf hakkındaki dini bilgi ve tutumlarını ölçebilmek amacıyla taslak bir form oluşturulmuştur. Bu cümleler örneklemin yaş grubu da dikkate alınarak 3'lü likert "Hayır, Katılmıyorum", “Kısmen Katılıyorum”, Evet, Tamamen Katılıyorum” şeklinde derecelenmiştir. Daha sonra hazırlanan taslak form, alanda uzman 2 öğretim üyesine sunulmuş, uzmanlardan maddeleri uygunluk ve ifade şekli açısından değerlendirme yapmaları istenmiştir. Uzmanların görüş ve önerileri doğrultusunda formda bazı sorular anlaşılırlık ve uygunluk açısından düzeltilmiş ve son hali verilen bu form 6 . Sınıfta 3 farklı okulda öğrenim gören 
100 öğrenciye ön deneme için uygulanmıştır. Ön uygulama ile elde edilen veriler üzerinde anketin geçerlik ve güvenirlik analizleri yapılmış; formun genel güvenirliği $\alpha=, 698$ olarak bulunmuştur. Formun faktör analizi için uygunluğunu tespit edebilmek için; Kmo ve Küresellik testi analizi uygulanmıştır. Yapılan analiz sonucunda KMO değerinin 0,657 küresellik testi değerinin ise $(X 2=215,267 \mathrm{p}<.05), 05^{\prime}$ den küçük olduğu ve faktör analizi için uygun olduğu görülmüştür. Faktör yapılarının nasıl olduğunu belirleyebilmek amacıyla açımlayıcı faktör analizi (AFA)'ya başvurulmuş ve Temel Bileşenler Analizi (Principal Component Analysis) tercih edilmiştir. uygulanan dik Döndürme (Varimax Rotation) işleminde faktör sayısı için herhangi bir sınırlama getirilmemiş ve özdeğeri (eigen value) 1.00 'den büyük olanlar olarak belirlenmiştir. Faktör yüklerinin alt kesme noktası olarak ,35 belirlenmiştir. Birden fazla faktörde yer alan ve aralarındaki faktör yük değer farkları 0.10 ve daha az olan maddenin elenmesi kuralı esas alınmıştır. Analiz sonucunda maddelerin özdeğeri birden büyük 2 faktörde toplandığı ve 2 faktörün açıkladığı varyans oranın \% 57,625 olduğu görülmüştür. Madde toplam korelasyonları incelendiğinde maddelerden hiçbirinin , 35'in altında yer almadığı ve birden fazla faktörde yer alan ve aralarındaki yük değer farkının $0.10^{\prime}$ dan daha az olan madde bulunmadığı tespit edilmiştir. Daha sonra faktör sayısına karar vermek için çizgi grafiği incelenmiş (Şekil 1) ve ölçeğin 2 faktörlü bir yapıya uygun olduğuna karar verilmiştir. Dik döndürme tekniklerinden de varimax ile elde edilen veriler aşağıda paylaşılmıştır. (Tablo 1)

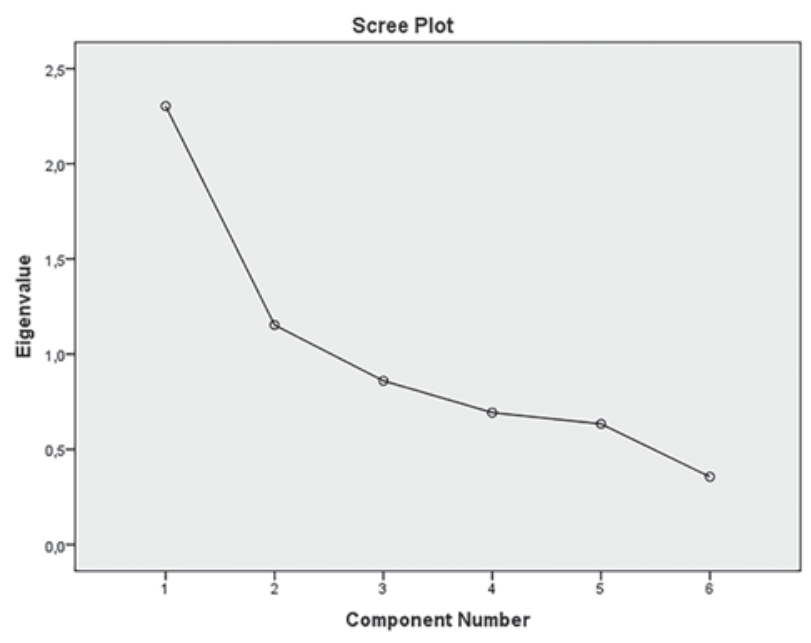

Şekil 1: Çizgi grafiği 
Tablo 1: İsrafa Karşı Farkındalık ölçeğinde yer alan maddelerin faktörlere göre dağılımı ve faktör yükleri

\begin{tabular}{|c|c|c|c|}
\hline Boyut & Maddeler & $\begin{array}{l}\text { Faktör } \\
\text { yük } \\
\text { değeri }\end{array}$ & Güvenirlik \\
\hline \multirow{2}{*}{$\begin{array}{l}\text { Dini } \\
\text { Bilgi }\end{array}$} & $\begin{array}{l}\text { Hz. Muhammed'in israf ile ilgili hadisleri ve içerikleri } \\
\text { hakkında bilgim var }\end{array}$ & ,886 & \multirow{2}{*}{,746 } \\
\hline & $\begin{array}{l}\text { Kuran-1 Kerim'de yer alan israf ile ilgili konular hakkında } \\
\text { bilgim var }\end{array}$ & 826 & \\
\hline \multirow{4}{*}{$\begin{array}{l}\text { Dini } \\
\text { Tutum }\end{array}$} & $\begin{array}{l}\text { Allah'ın bize verdiği nimetlerin (sahip olduğumuz şeylerin) } \\
\text { kıymetini bilmeliyiz }\end{array}$ & ,745 & \multirow{4}{*}{, 567} \\
\hline & Dini inançlarım beni daha tutumlu olmaya yöneltiyor & ,640 & \\
\hline & $\begin{array}{l}\text { İsrafı önlemek için gayret ettiğimde Allah'ın } \\
\text { rızasına kazanırım }\end{array}$ & ,606 & \\
\hline & $\begin{array}{l}\text { Herhangi bir şeyi israf ettiğimi fark ettiğimde dini açıdan } \\
\text { rahatsız olurum }\end{array}$ &, 527 & \\
\hline
\end{tabular}

Tabloda da görüldügü üzere 2 maddeden oluşan birinci faktör, öğrencilerin, israf hakkındaki dini bilgi düzeylerini ortaya koymaktadır. Faktör bu nedenle "Dini Bilgi" olarak adlandırılmıştır. Boyutun açıkladığı varyans oranı $\% 19,224$; en düşük faktör yükü ,82; en yüksek faktör yükü ,88' dir. İkinci faktör 4 maddeden oluşmuş ve "Dini Tutum" olarak isimlendirilmiştir. Faktör öğrencilerin, israfa karşı dini tutum düzeylerini ortaya koymaktadır. Boyutun açıkladığı varyans oranı \%38,396; en düşük faktör yükü ,52; en yüksek faktör yükü ,74'tür. İki faktörün açıkladığı toplam varyans oranı $\% 57,620$ 'dir.

\subsection{2. İsrafa Karşı Farkındalık Ölçeği (İKFÖ)}

Araştırmanın amacına yönelik olarak örneklem grubunun israfa yönelik farkındalık düzeylerini ölçmek amacıyla araştırmacı tarafından "İsrafa karşı farkındalık" ölçeği geliştirilmiştir. Ölçeği geliştirmeden önce ilgili literatür taranmış ve madde havuzu oluşturulmuştur. Bu madde havuzundan hareketle 30 maddelik taslak bir form oluşturulmuş ve bu form kapsam ve görünüş geçerliliği için konu uzmanlarına görüşleri almak için gönderilmiştir. Uzmanları görüş ve önerileri doğrultusunda taslak formdan bazı maddeler çıkartılmış, bazı maddelerde de düzeltmeler yapılmıştır. 3'lü likert şeklinde hazırlanmış olan ("Hayır, Katılmıyorum", "Kısmen Katılıyorum", Evet, Tamamen Katıl1yorum") ve 20 maddeden oluşan form, ön deneme için hazır hale getirilmiştir. Daha sonra bu form Isparta il merkezinde 3 farklı okulda öğrenim gören 100 öğrenciye ön uygulama yapılmıştır. Ön uygulama ile elde edilen veriler 
üzerinde anketin geçerlik ve güvenirlik analizleri yapılmıştır. Buna göre 20 maddeden oluşan formun genel güvenirliği $\alpha=, 770$ olarak bulunmuştur.

Daha sonra faktör analizi için uygunluğunu tespit edebilmek için; Kmo ve Küresellik testi analizi yapılmış, KMO değerinin 0,607 küresellik testi değerinin ise $(X 2=363,763 p<.05), 05^{\prime}$ den küçük olduğu ve faktör analizi için uygun olduğu görülmüştür. Daha sonra faktör yapılarının nasıl olduğunu belirleyebilmek için açımlayıcı faktör analizi (AFA) yapılmıştır. Burada Temel Bileşenler Analizi (Principal Component Analysis) tercih edilerek, veriler de Dik Döndürme (Varimax Rotation) işlemine de tabi tutulmuştur. Faktör sayısı için herhangi bir sinırlama getirilmemiş ve özdeğeri (eigen value) 1.00'den büyük olanlar olarak belirlenmiştir. Faktör yüklerinin alt kesme noktası olarak, 35 belirlenmiştir. Birden fazla faktörde yer alan ve aralarındaki faktör yük değer farkları 0.10 ve daha az olan maddenin elenmesi kuralı esas alınmıştır. Yapılan analiz sonucunda maddelerin özdeğeri birden büyük 6 faktörde topland1ğ1 ve 6 faktörün açıkladığı varyans oranın \%64 olduğu görülmüştür. Madde toplam korelasyonları incelendiğinde maddelerden hiçbirinin ,35'in altında yer almadığ 1 ve birden fazla faktörde yer alan ve aralarındaki yük değer farkının 0.10 'dan daha az olan madde bulunmadığı tespit edilmiştir. Daha sonra faktör sayısına karar vermek için çizgi grafiği incelenmiş (Şekil 2) ve ölçeğin 5 faktörlü bir yapıya uygun olduğuna karar verilmiştir.

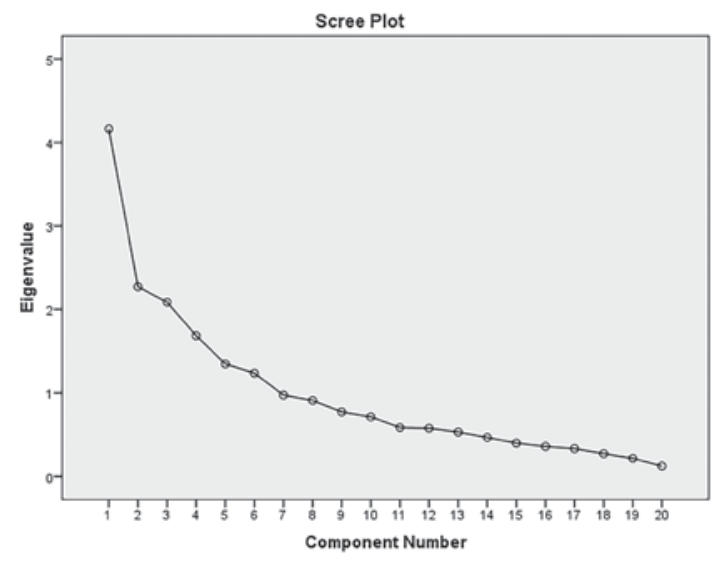

Şekil 2: Çizgi grafiği

Daha sonra faktör döndürme işlemi yapılmış, dik ve eğik döndürme yöntemlerinden dik döndürme, dik döndürme tekniklerinden de varimax tercih edilmiştir. Elde edilen veriler aşağıda paylaşılmıştır. 
Tablo 2: İsrafa Karşı Farkındalık ölçeğinde yer alan maddelerin faktörlere göre dağılımı ve faktör yükleri

\begin{tabular}{|c|c|c|c|}
\hline Boyut & Maddeler & $\begin{array}{l}\text { Faktör } \\
\text { yük } \\
\text { değeri }\end{array}$ & Güvenirlik \\
\hline \multirow{4}{*}{$\begin{array}{l}\text { Elektrik } \\
\text { İsrafi }\end{array}$} & $\begin{array}{l}\text { Bir odadan diğerine geçerken lambayı söndürmeden } \\
\text { bıraktığım zamanlar olur* }\end{array}$ & 0,77 & \multirow{4}{*}{ 710 } \\
\hline & $\begin{array}{l}\text { Elektrik israfının, var olan doğal kaynaklarımızı } \\
\text { (örneğin su) ve milli gelirimizi azalttığını } \\
\text { düşünüyorum }\end{array}$ & 0,69 & \\
\hline & $\begin{array}{l}\text { Gereksiz yere yanan bir lamba gördüğümde hemen } \\
\text { kapatırım }\end{array}$ & 0,57 & \\
\hline & $\begin{array}{l}\text { Enerji israfını önleme konusunda arkadaşlarımı } \\
\text { uyarırım }\end{array}$ & 0,57 & \\
\hline \multirow{4}{*}{$\begin{array}{l}\text { Ekmek } \\
\text { İsrafi }\end{array}$} & $\begin{array}{l}\text { Dünyada israf edilen ekmeğe harcan para ile ihtiyacı } \\
\text { olan birçok kişiye yardım edebilirdik }\end{array}$ & 0,84 & \multirow{4}{*}{669} \\
\hline & $\begin{array}{l}\text { Bayatlayan ekmekleri israf etmemek için aileme her } \\
\text { zaman destek veririm }\end{array}$ & 0,62 & \\
\hline & $\begin{array}{l}\text { Ekmek israfı yapan birini gördüğümde uyarma gereği } \\
\text { hissederim }\end{array}$ & 0,60 & \\
\hline & Sofrada yiyebileceğimden fazla ekmek almam & 0,59 & \\
\hline \multirow{5}{*}{$\begin{array}{l}\text { Kâğıt } \\
\text { İsrafi }\end{array}$} & $\begin{array}{l}\text { Arkadaşlarımı ve çevremdeki insanları kağıt israfı } \\
\text { yapmamaları konusunda uyarırım }\end{array}$ & 0,73 & \multirow{5}{*}{652} \\
\hline & $\begin{array}{l}\text { Kâğıt israfı yapılarak ağaçlara zarar verildiğine } \\
\text { inanıyorum }\end{array}$ & 0,72 & \\
\hline & $\begin{array}{l}\text { Defterimin artan yapraklarını, başka bir ders için } \\
\text { kullanarak değerlendirmeye çalışırım }\end{array}$ & 0,64 & \\
\hline & $\begin{array}{l}\text { Tekrar kullanılmayacak olan kâğıtları geri dönüşüm } \\
\text { kutusuna atarım }\end{array}$ & 0,48 & \\
\hline & $\begin{array}{l}\text { Ülkemizde ve dünyada bir yılda israf edilen kağıt } \\
\text { miktarı konusunda bilgi sahibiyim }\end{array}$ & 0,41 & \\
\hline \multirow{4}{*}{ Su İsrafi } & $\begin{array}{l}\text { Herhangi bir musluğu gereksiz yere akarken } \\
\text { gördüğümde hemen kapatırım }\end{array}$ & 0,75 & \multirow{4}{*}{,705 } \\
\hline & $\begin{array}{l}\text { Dişlerimi fırçaladığım süre boyunca musluğu hep açık } \\
\text { tutarım* }\end{array}$ & 0,72 & \\
\hline & $\begin{array}{l}\text { Okulda veya evde ellerimi yıkarken suyu gereğinden } \\
\text { fazla kullanmamaya özen gösteririm }\end{array}$ & 0,66 & \\
\hline & $\begin{array}{l}\text { Suyu gereğinden fazla kullanan birini gördüğümde o } \\
\text { kişiyi uyarırım }\end{array}$ & 0,60 & \\
\hline \multirow{3}{*}{$\begin{array}{l}\text { Zaman } \\
\text { İsrafi }\end{array}$} & $\begin{array}{l}\text { Boş zamanlarımı doğru değerlendiremediğimi } \\
\text { düşünüyorum* }\end{array}$ & 0,69 & \multirow{3}{*}{, 507} \\
\hline & $\begin{array}{l}\text { Internette ve televizyon karşısında çok fazla vakit } \\
\text { geçirmek zaman israfıdır }\end{array}$ & 0,63 & \\
\hline & $\begin{array}{l}\text { Zorunlu durumlar dışında bilgisayar başında çok vakit } \\
\text { harcıyorum* }\end{array}$ & 0,53 & \\
\hline
\end{tabular}

* Olumsuz ifadeler tersten kodlanmalıdır 
Tabloda da görüldüğü üzere birinci faktörde 4 madde yer almıştır. Faktör öğrencilerin, elektrik israfına karşı farkındalık düzeylerini ortaya koymaktadır. Faktör bu nedenle "elektrik israfı" olarak adlandırılmıştır. Boyutun açıkladığ1 varyans oranı $\% 20,81$; en düşük faktör yükü ,57; en yüksek faktör yükü ,77'dır. İkinci faktör 4 maddeden oluşmuş ve "ekmek israfı" olarak isimlendirilmiştir. Faktör öğrencilerin, ekmek israfına karşı farkındalık düzeylerini ortaya koymaktadır. Boyutun açıkladığı varyans oranı \%11,352; en düşük faktör yükü ,59; en yüksek faktör yükü ,84' dir. "Kâğıt israfı" olarak adlandırılmış olan üçüncü faktör 5 maddeden oluşmuştur. Boyutun açıkladığı varyans oranı \% 10,433; faktör yük değerleri ,41 ile,77 arasında değişmektedir. "Su israfı" olarak adlandırılmış olan dördüncü faktör 4 maddeden oluşmuştur. Faktör öğrencilerin su israfına karşına farkındalık düzeylerini ortaya koymaktadır. Boyutun açıkladığı varyans oranı \% 8,423'tür. Faktör yük değerleri ise ,60 ile ,75 arasında değişmektedir. Son faktörde ise 3 madde yer almıştır. Faktör öğrencilerin zaman israfına karşına farkındalık düzeylerini ortaya koymaktadır. Bu nedenle "zaman israfı" şeklinde isimlendirilmiştir. Boyutun açıkladığı varyans oranı \% 6,731 iken, faktör yük değerleri ,53 ile ,69 arasında değişmektedir. Beş faktörün açıkladığı toplam varyans oranı \%57,751'dir.

\subsection{Veri Toplama Araçlarının Uygulanması}

Araştırmanın verileri, Isparta Çünür Toki Ortaokulunda öğrenim gören 59 öğrenciden elde edilmiştir. Araştırmacı tarafından hazırlanan etkinlik temelli program uygulanmadan önce katılımcılara İsrafa Karşı Farkındalık ve Dini Bilgi ve Tutum Ölçekleri uygulanmıştır. Araştırmacı tarafından öğrencilerin israf konusunda dini farkındalık kazanmaları hedeflenen proje tabanlı ve etkinlik temelli yaklaşımı temele alan DKAB dersi ile bütünleştirilmiş teori ve uygulama ağırlıklı bir ders programı hazırlanmıştır. Bu program ders süresi ve ders dışı zamanlarda uygulanmak üzere iki aşamadan oluşan etkinlikleri içermektedir. Ders içi etkinliklerinin içeriğini, israf konusundaki dini bilgi ve tutumlarına yönelik öğrenci merkezli etkinlikler; ders dışı zamanlardaki etkinliklerin içeriğini ise; israfa karşı farkındalıklarını arttırmayı hedefleyen, öğrencinin öğrenmesinin sorumluluğunu aldığı proje tabanlı etkinlikler oluşturmuştur. Daha sonra bu program 6 hafta süre ile uygulanmıştır. Hazırlanan program sona erdiğinde ise aynı ölçekler katılımcılara tekrar uygulanmış ve her iki uygulamada elde edilen bulgular, istatistikî işlemlere tabi tutulmuş ve yorumlanmıştır.

\subsection{Verilerin Analizi}

Katılımcıların ölçeklere yönelik öntest-sontest ortalama puanlarının normal dağılım göstermesi nedeniyle verilerin analizinde gruplar arası farkın belir- 
lenmesinde parametrik testlerden ilişkili örneklemler için (paired samples) t-testi, independent sample t testi ve Tek Yönlü Varyans Analizi (Anova) kullanılmıştır. Çalışmadan elde edilen veriler SPSS 20 (Statistical Package for the Social Sciences) programı ile analiz edilmiştir.-Faktörlerde bulunan olumsuz ifadelerin analiz yapılırken olumluya çevrilmesi gerekmektedir.

\section{Bulgular}

\subsection{DBTÖ ile İKFÖ Arasındaki İlişkiye Ait Bulgular}

Tablo 3: DBTÖ ile İKFÖ Arasındaki Korelasyon

\begin{tabular}{|c|c|c|c|c|c|c|c|c|c|c|}
\hline & & $\begin{array}{l}: 0 \\
: 0 \\
0 \\
0\end{array}$ & 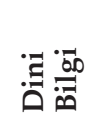 & 节志 & 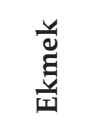 & 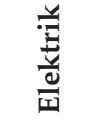 & के & 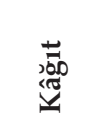 & $\underset{\text { స్ }}{\text { స్ }}$ & $\begin{array}{l}0 \\
\text { : } \\
\underline{I} \\
.\end{array}$ \\
\hline DBTÖ & $\begin{array}{l}\text { Pearson } \\
\text { Correlation }\end{array}$ & 1 & & & & & & & & \\
\hline $\begin{array}{l}\text { Dini } \\
\text { Bilgi }\end{array}$ & $\begin{array}{l}\text { Pearson } \\
\text { Correlation }\end{array}$ &, $803^{* *}$ & 1 & & & & & & & \\
\hline $\begin{array}{l}\text { Dini } \\
\text { Tutum }\end{array}$ & $\begin{array}{l}\text { Pearson } \\
\text { Correlation }\end{array}$ & $918^{* *}$ &, $501^{* *}$ & 1 & & & & & & \\
\hline Ekmek & $\begin{array}{l}\text { Pearson } \\
\text { Correlation }\end{array}$ & 0,194 & 0,167 & 0,171 & 1 & & & & & \\
\hline Elektrik & $\begin{array}{l}\text { Pearson } \\
\text { Correlation }\end{array}$ & 0,217 & 0,067 & $270^{*}$ & 0,152 & 1 & & & & \\
\hline $\mathrm{Su}$ & $\begin{array}{l}\text { Pearson } \\
\text { Correlation }\end{array}$ &, $379^{* *}$ & 0,214 &, $407^{* *}$ & $-0,069$ & , 258 & 1 & & & \\
\hline Kâğıt & $\begin{array}{l}\text { Pearson } \\
\text { Correlation }\end{array}$ & 0,237 & , 268* & 0,166 & 0,191 & 0,211 & $406^{* *}$ & 1 & & \\
\hline Zaman & $\begin{array}{l}\text { Pearson } \\
\text { Correlation }\end{array}$ & 0,093 & 0,096 & 0,071 & 0,06 & 0,12 & $-0,082$ & $-0,165$ & 1 & \\
\hline İKFÖ & $\begin{array}{l}\text { Pearson } \\
\text { Correlation }\end{array}$ & $405^{* *}$ &, $304^{*}$ &, $386^{* *}$ &, $501^{* *}$ &, $656^{* *}$ &, $542^{* *}$ &, $701^{* *}$ & 0,25 & 1 \\
\hline \multicolumn{2}{|c|}{ ** < 0.01 level (2-tailed). } & \multicolumn{9}{|c|}{${ }^{*}<0.05$ level (2-tailed } \\
\hline
\end{tabular}


Tabloda görüldüğü üzere örneklem grubun israf konusundaki dini bilgi ve tutumları ile israfa karşı farkındalık düzeyleri arasındaki ilişkiye yönelik gerçekleştirilen korelasyon analizi sonucunda; israf konusunda dini bilgi, tutum ve farkındalık arasında pozitif yönde anlamlı bir ilişki bulunmuştur. Buna göre; öğrencilerin israf konusundaki dini bilgileri ve yaklaşımları arttıkça israfa karşı farkındalıkları da artmaktadır (,405). Bulguları, aşkın değerlerin içkin değerlerin içselleşmesine sağladığı katkı olarak görmek mümkündür. Çünkü değerin sağladığı aşkınlık arttıkça değerin bilgi, tutum ve davranış olarak içselleşmesi de artmaktadır.

\section{2. Örneklem Grubun DBTÖ Ön Test ve Son Test Puanlarına İlişkin Bulgular}

Tablo 4: DBTÖ Ön Test ve Son Test Puanları

\begin{tabular}{llcccccc}
\hline & Ölçüm & $\mathbf{N}$ & $\mathbf{X}$ & $\mathbf{S S}$ & $\mathbf{t}$ & $\mathbf{S d}$ & $\mathbf{p}$ \\
\hline \multirow{2}{*}{ DBTÖ } & Ön test & 59 & 2,14 & 0,36 & $-9,7$ & 58 & $\mathbf{0 , 0 0}$ \\
& Son test & 59 & 2,68 & 0,39 & & & \\
\hline \multirow{2}{*}{ Dini Bilgi } & Ön test & 59 & 1,40 & 0,53 & $-11,881$ & 58 & $\mathbf{0 , 0 0}$ \\
& Son test & 59 & 2,53 & 0,53 & & & \\
\hline \multirow{2}{*}{ Dini Tutum } & Ön test & 59 & 2,50 & 0,45 & $-4,131$ & 58 & $\mathbf{0 , 0 0}$ \\
& Son test & 59 & 2,75 & 0,40 & & & \\
\hline
\end{tabular}

Tablo incelendiğinde, katılımcı grubu oluşturan öğrencilerin DBTÖ toplam ve alt boyutlarına yönelik ön test ve son test ortalamaları arasında son test lehine bir farkın olduğu görülmüştür. Grubun ön-test ve son-test puanları arasındaki bu farkın istatistiksel olarak anlamlı olup olmadığını tespit edebilmek için paired sample t-testi uygulanmış ve bu farkın anlamlı olduğu bulunmuştur. Buna göre; DKAB dersinde proje tabanlı ve etkinlik temelli oluşturulan değer öğretiminin örneklem grubunun israf konusundaki dini tutumları üzerinde olumlu etkiye neden olduğu söylenebilir. 
3.3. Örneklem Grubun DBTÖ Ön Test ve Son Test Puanlarına İlişkin Bulgular

Tablo 5: İKFÖ Ön Test ve Son Test Puanları

\begin{tabular}{llcccccc}
\hline & Ölçüm & $\mathbf{N}$ & $\mathbf{X}$ & $\mathbf{S S}$ & $\mathbf{t}$ & $\mathbf{S d}$ & $\mathbf{p}$ \\
\hline \multirow{2}{*}{ İKFö } & Ön test & 59 & 2,13 & 0,32 & $-7,319$ & 58 & $\mathbf{0 , 0 0}$ \\
& Son test & 59 & 2,45 & 0,19 & & & \\
\hline \multirow{2}{*}{ Ekmek } & Ön test & 59 & 2,15 & 0,57 & $-6,522$ & 58 & $\mathbf{0 , 0 0}$ \\
& Son test & 59 & 2,68 & 0,34 & & & \\
\hline \multirow{2}{*}{ Elektrik } & Ön test & 59 & 2,23 & 0,48 & $-2,279$ & 58 & $\mathbf{0 , 0 3}$ \\
& Son test & 59 & 2,40 & 0,37 & & & \\
\multirow{2}{*}{ Su } & Ön test & 59 & 2,39 & 0,53 & $-0,663$ & 58 & 0,51 \\
& Son test & 59 & 2,44 & 0,28 & & & \\
\hline \multirow{2}{*}{ Kăğit } & Ön test & 59 & 1,81 & 0,48 & $-12,065$ & 58 & $\mathbf{0 , 0 0}$ \\
& Son test & 59 & 2,60 & 0,36 & & & \\
\hline \multirow{2}{*}{ Zaman } & Ön test & 59 & 1,96 & 0,49 & 2,306 & 58 & $\mathbf{0 , 0 3}$ \\
& Son test & 59 & 2,18 & 0,36 & & &
\end{tabular}

Araştırmanın desenine uygun olarak gerçekleştirilen işlem sonunda elde edilen bulgulara göre; deney grubunun İKFÖ ve alt boyutlarına yönelik ön test-son test puanları arasında farklılaşma olduğu görülmüştür. Bu farkın anlamlı olup olmadığını tespit etmek amacıyla yapılan paired sample t-testi sonucunda; İKFÖ ve alt boyutlarındaki (Ekmek; elektrik, kağıt, zaman) farkın istatistiki olarak anlamlı olduğu bulunmuştur $(p>, 05)$. Öğrencilerin ön testson test puanları arasında fark sadece İKFÖ ölçeğinin alt boyutu olan su boyutunda anlamlı çıkmamıştır. 


\section{4. Örneklem Grubun DBTÖ ve İKFÖ Puanlarının Cinsiyet Değişkenine Göre Farklılaşma Durumu}

Tablo 6: Cinsiyete Göre Örneklem Grubun DBTÖ ve İKFÖ Puanları

\begin{tabular}{llllllll}
\hline & Ölçüm & $\mathbf{N}$ & $\mathbf{X}$ & SS & $\mathbf{t}$ & Sd & p \\
\hline \multirow{2}{*}{ DBTÖ Ön Test } & Kız & 29 & 2,24 & 0,33 & 2,146 & 57 & $\mathbf{0 , 0 4}$ \\
& Erkek & 30 & 2,04 & 0,37 & & & \\
DBTÖ Son Test & K1z & 29 & 2,84 & 0,19 & 3,635 & 39,532 & $\mathbf{0 , 0 0}$ \\
& Erkek & 30 & 2,52 & 0,45 & & & \\
İKFÖ Ön Test & Kız & 29 & 2,18 & 0,33 & 1,172 & 57 & 0,25 \\
& Erkek & 30 & 2,09 & 0,30 & & & \\
İKFÖ Son Test & Kiz & 29 & 2,48 & 0,14 & 1,422 & 47,368 & 0,16 \\
& Erkek & 30 & 2,42 & 0,23 & & & \\
\hline
\end{tabular}

Araştırmada cinsiyet değişkeninin deney grubunun ön test-son test puanlarında anlamlı düzeyde farklılık oluşturup oluşturmadığı tespit edilmeye çalışılmıştır. Bu amaçla uygulanan bağımsız örneklem $t$ testi sonucunda; deney grubunun DBTÖ ve İKFO ön tst- son test puanlarının cinsiyete göre farklılık gösterdiği; fakat bu farkın sadece DBTÖ puanlarında anlamlı düzeyde farklılaştığı belirlenmiştir ( $p>, 05)$. Buna göre kız öğrencilerin DBTÖ ortalamaları erkeklere oranla daha yüksektir. Bulgular, kız öğrencilerin israf konusunda dini bilgi ve tutumlarının daha fazla olduğunu ve yapılan uygulama sonucunda daha fazla artış olduğunu ortaya koymaktadır. 
3.5. Örneklem Grubun DBTÖ ve İKFÖ Puanlarının En Çok Yapılan İsraf Türü Değişkenine Göre Farklılaşma Durumu

Tablo 7: En Çok Yapılan İsraf Türüne Göre Örneklem Grubun DBTÖ ve İKFÖ Puanları

\begin{tabular}{|c|c|c|c|c|}
\hline & Ölçüm & $\mathbf{N}$ & $X$ & SS \\
\hline \multirow{6}{*}{ DBTÖ Ön Test } & Elektrik & 16 & 2,02 & 0,34 \\
\hline & Zaman & 26 & 2,12 & 0,34 \\
\hline & Kâğıt & 3 & 2,33 & 0,00 \\
\hline & Ekmek & 8 & 2,08 & 0,36 \\
\hline & $\mathrm{Su}$ & 6 & 2,50 & 0,45 \\
\hline & Toplam & 59 & 2,14 & 0,36 \\
\hline \multirow{6}{*}{ DBTÖ Son Test } & Elektrik & 16 & 2,51 & 0,49 \\
\hline & Zaman & 26 & 2,79 & 0,19 \\
\hline & Kâğıt & 3 & 2,89 & 0,19 \\
\hline & Ekmek & 8 & 2,46 & 0,56 \\
\hline & $\mathrm{Su}$ & 6 & 2,83 & 0,26 \\
\hline & Toplam & 59 & 2,68 & 0,39 \\
\hline \multirow{6}{*}{ İKFÖ Ön Test } & Elektrik & 16 & 2,15 & 0,32 \\
\hline & Zaman & 26 & 2,16 & 0,24 \\
\hline & Kâğıt & 3 & 2,17 & 0,40 \\
\hline & Ekmek & 8 & 1,96 & 0,34 \\
\hline & $\mathrm{Su}$ & 6 & 2,17 & 0,52 \\
\hline & Toplam & 59 & 2,13 & 0,32 \\
\hline \multirow{6}{*}{ İKFÖ Son Test } & Elektrik & 16 & 2,39 & 0,24 \\
\hline & Zaman & 26 & 2,48 & 0,18 \\
\hline & Kâğıt & 3 & 2,43 & 0,10 \\
\hline & Ekmek & 8 & 2,51 & 0,20 \\
\hline & $\mathrm{Su}$ & 6 & 2,42 & 0,10 \\
\hline & Toplam & 59 & 2,45 & 0,19 \\
\hline
\end{tabular}

Tablo 7'de israf türü değişkenine göre, öğrencilerin DBTÖ ve İKFÖ ortalamalarına yer verilmiştir. Tablodaki veriler incelendiğinde; DBTÖ’́de ön test ortalamalarının 2,02 ile 2,5 arasında değiştiği, en yüksek ortalamaya su israfı yaptığını düşünen grubun; en düşük ortalamaya da elektrik israfı yapıldığını 
düşünen grubun sahip olduğu; DBTÖ'de son test ortalamalarında ise; ortalamaların 2,46 ile 2,83 arasında değiştiği; en yüksek ortalamaya su israfı yapıldığını düşünen grubun, en düşük ortalamaya ise ekmek israfı yaptığını düşünen grubun sahip olduğu görülmüştür. İKFÖ ön test ortalamalarının 1,96 ile 2,17 arasında değiştiği, en yüksek ortalamaya su ve kâğıt israfı yapıldığını düşünen grubun; en düşük ortalamaya da ekmek israfı yapıldığını düşünen grubun sahip olduğu; İKFÖ'de son test ortalamalarında ise; ortalamaların 2,39 ile 2,51 arasında değiştiğii en yüksek ortalamaya ekmek israfı yapıldığını düşünen grubun, en düşük ortalamaya ise elektrik israfı yapıldığını düşünen grubun sahip olduğu görülmüştür. Gruplar arasındaki bu farkın anlamlı olup olmadığını belirlemek amacıyla da tek yönlü varyans analizi yapılmış, elde edilen sonuçlara aşağıda yer verilmiştir.

Tablo 8: Örneklem Grubun DBTÖ ve İKFÖ Puanlarının En Çok Yapılan İsraf Türüne Göre Farklılaşma Durumları

\begin{tabular}{|c|c|c|c|c|c|c|c|}
\hline & 坣疍 & 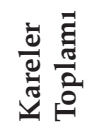 & ర్ర & 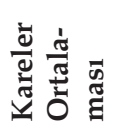 & 工 & $a$ & \\
\hline \multirow{3}{*}{$\begin{array}{l}\text { DBTÖ Ön } \\
\text { Test }\end{array}$} & $\begin{array}{l}\text { Between } \\
\text { Groups }\end{array}$ & 1,157 & 4 & 0,289 & 2,411 & 0,06 & \\
\hline & $\begin{array}{l}\text { Within } \\
\text { Groups }\end{array}$ & 6,48 & 54 & 0,12 & & & \\
\hline & Total & 7,637 & 58 & & & & \\
\hline \multirow{3}{*}{$\begin{array}{l}\text { DВTÖ } \\
\text { Son Test }\end{array}$} & $\begin{array}{l}\text { Between } \\
\text { Groups }\end{array}$ & 1,431 & 4 & 0,358 & 2,693 & 0,04 & $\begin{array}{l}\text { Elektrik- } \\
\text { Zaman }\end{array}$ \\
\hline & $\begin{array}{l}\text { Within } \\
\text { Groups }\end{array}$ & 7,173 & 54 & 0,133 & & & $\begin{array}{l}\text { Ekmek- } \\
\text { Zaman }\end{array}$ \\
\hline & Total & 8,604 & 58 & & & & \\
\hline \multirow{3}{*}{$\begin{array}{l}\text { İKFÖ Ön } \\
\text { Test }\end{array}$} & $\begin{array}{l}\text { Between } \\
\text { Groups }\end{array}$ & 0,27 & 4 & 0,067 & 0,661 & 0,622 & \\
\hline & $\begin{array}{l}\text { Within } \\
\text { Groups }\end{array}$ & 5,514 & 54 & 0,102 & & & \\
\hline & Total & 5,784 & 58 & & & & \\
\hline \multirow{3}{*}{$\begin{array}{c}\text { İKFÖ Son } \\
\text { Test }\end{array}$} & $\begin{array}{l}\text { Between } \\
\text { Groups }\end{array}$ & 0,1 & 4 & 0,025 & 0,668 & 0,617 & \\
\hline & $\begin{array}{l}\text { Within } \\
\text { Groups }\end{array}$ & 2,013 & 54 & 0,037 & & & \\
\hline & Total & 2,112 & 58 & & & & \\
\hline
\end{tabular}


Tablo da görüldüğü üzere, israf türü değişkeni, deney grubunun sadece DBTÖ son test ile ilgili puanlarında anlamlı düzeyde farklılık oluşturmuştur. $\mathrm{Bu}$ farklılığın hangi gruplar arasında olduğunu tespit amacıyla gerçekleştirilen çoklu araştırmaya göre; elektrik israfı $(X=2,51)$ ile zaman israfı $(X=2,79)$; ekmek israfı $(X=2,46)$ ile zaman israfı $(X=2,79)$ yapıldı ğını düşünen grupların arasında olduğu belirlenmiştir. Bulgular, uygulanan programın daha çok zaman israfı yapıldığını düşünen grubun diğer gruplara oranla(ekmek-elektrik) oranla israf konusundaki dini bilgi ve tutumlarında daha çok etkili olduğunu göstermiştir, denilebilir.

\section{Sonuç}

Temel hayat tarzı dini bağlılık üzerine kurulmuş olan bireyin sahip olduğu dini tutumun, onun diğer tutum ve davranışlarını, değerlerini pozitif veya negatif olarak takviye edeceği unutulmamalıdır. ${ }^{26} \mathrm{Bu}$ nedenle "israfla mücadelede veya israf tüketimini asgariye indirmede dini referanslardan, dinin motivasyonundan azami derecede istifade etmek ve yararlanmak gerekir. Çünkü dini değerler Müslüman bir toplumda oldukça büyük önem arz etmekte ve insanlar üzerinde olumlu etki yapmaktadır. Din, insan ve toplum hayatında yapıcılık bağlamında fevkalade etkili ve yaptırım gücü kuvvetli olan bir kurumdur. Özellikle de bu konuda dinimizin uygulayıcısı ve tebliğcisi konumunda olan Hz. Peygamber'in hadislerinden istifade etmek elzemdir. Insanın, diğer insanlarla olan ilişkisi konusunda önemli ölçüde ilkeler ve prensipler ihtiva eden hadisler söz konusudur." 27

DKAB dersinin öğrencilerin israf konusunda dini bilgi, tutum ve israfa karşı farkındalık düzeyleri üzerindeki etkisinin incelendiği bu çalışmada; öğrencilerin israf konusundaki dini bilgi ve tutumları arttıkça israfa karşı farkındalık düzeylerinin de arttığı; proje tabanlı ve aktif öğrenme merkezli gerçekleştirilen DKAB dersinin öğrencilerin DBTÖ ve İKFÖ ön test- son test puanlarında istatistiksel olarak anlamlı farklılaşmaya neden olduğu tespit edilmiştir. Sonuçlar dinin, değerler üzerindeki etkisini uygulamalı olarak ortaya koyması açısından oldukça önemlidir. Araştırmanın bir diğer sonucu ise; cinsiyet değişkenin öğrencilerin DBTÖ ön-son test puanlarında; israf türü değişkenin ise DBTÖ son test puanlarında anlamlı farklılaşmaya neden olduğudur.

26 Ali Ulvi Mehmedoğlu, "İlâhiyat Fakültesi Öğrencilerinin Değer Yönelimleri ve DindarlıkDeğer İlişkisi (M.Ü. İlâhiyat Fakültesi Örneği)", M.Ü. Illâhiyat Fakülttesi Dergisi 30 (2006): 138.

27 Sancaklı, Hadisler Çerçevesinde İsraf Olgusunun Analizi, 80. 
Literatürde araştırmamızın sonuçlarını destekleyen araştırma sonuçları bulunmaktadır. Örneğin dini inanç, tutum ve davranışların çevre duyarlılığına etkilerinin incelendiği bir araştırmada; kendisini dindar olarak niteleyen kişilerin çevre sorunları konusunda daha duyarlı olduğu; katılımcıların dini bilgi düzeyi yükseldikçe çevre sorunlarına duyarlılık düzeyinin de artmakta olduğu tespit edilmiştir. ${ }^{28}$ Cebeci'nin araştırmasında da öğrencilerin ahlaki tutum ve davranışlarında dini inançlarının ve DKAB derslerinin olumlu etkide bulunduğu; DKAB dersine ilgi duyan ve dersin olumlu etkisinden söz eden öğrencilerin ahlaki değer kazanımlarının daha yüksek olduğu sonuçlarına ulaşılmıştır. ${ }^{29}$

Konu ile ilgili Güleç, adil davranışlarda, din eğitim ve öğretimi ile dindarlığın rolünü bir alan araştırmasıyla tespit etmeye çalışmıştır. Güleç, araştırmasında «adil davranışlar gösterme» de, ailede alınan din eğitim ve öğretiminin, okullara göre daha etkili olduğunu tespit etmiş̧ir. İlahiyat Fakülteleri'ndeki din eğitim ve öğretimi, adil davranışlar göstermenin; «inanç-ibadet» yöneliminde istatistiksel açıdan olumlu etkiye sahip iken; ancak «israftan kaçınma» ve diğer yönelimlerinde, diğer fakülte ve bölüm öğrencilerine göre, anlamlı bir farklılık oluşturmamıştır. Araştırmada ayrıca dini bilgi seviyesi ile adil davranışların; «inanç-ibadet» düzeyi arasında olumsuz ilişki; «farkındalık» ve «emanet-doğruluk» düzeyi arasında olumlu ilişki bulunmuş; dinin etkisini hissetme ile ise adil davranışların; «inançibadet,» «farkındalık,» «emanet-doğruluk," ve "israftan kaçınma" düzeyleri arasında pozitif; "önyargıdan uzak olma” düzeyleri arasında negatif bir ilişki bulunmuştur. ${ }^{30}$

Bireyin yetişkinlik döneminde sahip olduğu yapı, alışkanlık, inanç ve değer yargılarının biçimlenmesinde çocukluk döneminde uygulanan eğitimin ve kazanılan davranışların önemi oldukça fazladır. Bu nedenle değer öğretiminin altın çağları çocukluk dönemidir. Fakat burada dikkat edilmesi gereken husus ise; uygulanacak değer eğitimi programının çocukların özelliklerine,

28 Vehbi Ünal, Çevre Sorunlar ve Dindarlık İlişkisi (Kayseri Örneği), (Doktora Tezi, Selçuk Üniversitesi, 2010).

29 Aylin Cebeci, İlköğretim Din Kültürü ve Ahlak Bilgisi Derslerinde Ahlaki Değerlerin Eğitimi ve Öğretimi, (Yüksek Lisans Tezi, Uludağ Üniversitesi, 2005).

30 Yasemin Güleç, Adil Davranışlar Göstermede Din Eğitiminin Rolü, (Doktora Tezi, Necmettin Erbakan Üniversitesi, 2014). 
gelişimine ve ihtiyaçlarına uygun olmasıdır. ${ }^{31}$ Biberci de araştırmasında çocukların değerleri içselleştirilmesinde dinin ve eğitiminin etkisini ortaya koyabilmek amacıyla, 2-7 yaş arası çocuklara sevgi ve merhamet değerlerinin hadisler ışı̆̆ında öğretiminin nasıl yapılacağını gelişim düzeylerini dikkate alarak ortaya koymaya çalışmıştır. ${ }^{32}$

Bilgi, değerin içselleştirilmesinde tek başına yeterli değildir. Önemli olan öğrenilmiş bilginin sosyal hayatta karşılı̆̆ının olması, çocuk tarafından tecrübe edilmesidir. Yaşanılan bu tecrübe, değerin çocuğun kişiliği ile bütünleşmesinde etkili olacaktır. Çünkü kişilik ile bütünleşmeyen değerlerin kalıcılığı ve sürekliliğinde sorun oluşabilir. Dolayısıyla değer öğretiminde dikkat edilmesi gereken temel ilkelerden biri, değerin çocuğun bilişsel, duyuşsal ve psikomotor olarak ifade edilen tüm öğrenme alanlarında hayat bulmasıdır. ${ }^{33}$ Ekmek israfı üzerine yapılan bir araştırmada; çalışmaya katılan öğrencilerin çoğunluğu ihtiyaç fazlası ekmek alımının, ekmek israfında etkili olduğunu belirtmiş ve çocuklar için hazırlanan ve uygulanan kampanyanın öğrencilerin dikkatini çektiği ve ekmek israfı konusunda bilinçlendirdiği sonucuna ulaşılmıştır. ${ }^{34}$

Bugün kitle iletişim araçlarının tüketim kültürünün yerleşmesindeki etkisi oldukça fazladır. Kitle iletişim araçları çocukların, tutum ve davranışları model alma yolu ile öğrendikleri temel kaynaklara dönüşmekte ve reklamlar, tv programları, sosyal medya gibi faktörler ile bireylerdeki tüketme arzusunu tetiklemektedir. Medya sadece çocukları değil yetişkinleri de aynı tehlike ile karşı kaşıya bırakmaktadır. Bu nedenle medyanın çocuklar ve bireyler üzerindeki etkisini azaltmanın yolu, bilinçli bir medya okuryazarı olmaktan geçmektedir. Medyayı bilinçli kullanan aileler, çocuklarını da bu konuda eğitebilecek ve israf batağına düşmüş, tüketim toplumu bir neslin yetişmemesi için elinden geleni yapacaktır.

İslam bireyin ve toplumun mutluluğunu ön planda tutarak her alanda itidalli olmayı, aşırıya kaçmamayı temel prensip olarak belirlemiştir. Çünkü İslam dinine göre onurlu bir yaşamın ve dindarlığın temel göstergelerinden

31 Mualla Selçuk, "Çocuğun Eğitiminde Dini Motifler", (Ankara: Türkiye Diyanet Vakfı Yayınları, 1991), 13

32 Fatmanur Biberci, 2-7 Yaş Arası Çocuklarda Sevgi ve Merhamet Değerlerinin Hadisler Işı̆̆ında Öğretimi, (Yüksek Lisans Tezi, Selçuk Üniversitesi, 2010).

33 Hüseyin Aydın, "Çocuğun Ailede Kazanacağı Önemli Bir Değer: Kanaatkârlık", Eğitime Bakış, 6/18, (2010): 55-58.

34 Çağrı Gümüş, Ekmek İsrafını Önleme Konulu Sosyal Sorumluluk Kampanyasına İlişkin Akademisyen, Uzman ve Öğrenci Görüşleri, (Doktora Tezi, Gazi Üniversitesi, 2015). 
biri, israf bataklığına düşmemektir. ${ }^{35}$ Dolayısıyla çocuklara yönelik değer eğitiminde temel amaç, çocuğun fıtratına uygun kişiliğinin gelişimine yardımcı olmak; bireyi ve toplumu mutlu kılacak özelliklerin devamlılığını sağlamak olmalıdır. ${ }^{36} \mathrm{Bu}$ nedenle çocuğun değerleri içselleştirmesinde öncelikle Kur'an'ın da ahlaki bir yaşam oluşturmada, insanlığa getirdiği en önemli değerlerden biri olan öz-denetim (otokontrol) prensibinin geliştirilmesi sağlanmalıdır. ${ }^{37} \mathrm{Bu}$ nedenle israf konusu öğretilirken, değer çocuklara "vicdani sorumluluk bilinci, dünya ve âhiret dengesini kurması gerektiği ve ebedi hayat inancl, yani ferdi çıkarlarıyla ve maddi değerlerini manevi değerlerle bütünleştirmesi gerektiği bilinci ile verilmelidir." ${ }^{\prime 38}$

\section{Kaynakça}

Abalı, Osman. İlk ve Ortä̈gretim Din Kültürü ve Ahlak Bilgisi Derslerinde Çevre Eğitimi. Yüksek Lisans Tezi, Çukurova Üniversitesi, 2014.

Akbaş, Oktay. "Değer Eğitimi Akımlarına Genel Bir Bakış". Değerler Eğitimi Dergisi 6/16 (2008): 9-27.

Ay, Mustafa Fatih. İlköğretim Din Kültürü ve Ahlak Bilgisi Derslerinde Hoşgörü Değerinin Öğretimi. Yüksek Lisans Tezi, Atatürk Üniversitesi, 2013.

Aydın, Mehmet Zeki - Akyol Gürler, Şebnem. Okulda Değerler Eğitimi Yöntemler Etkinlikler Kaynaklar. Ankara: Nobel Yayıncilik, 2012.

Aydın, Mehmet Zeki. “Okulda Çalışan Herkesin Görevi Olarak Değerler Eğitimi”. Erişim: 1 Nisan 2017. http: / / www.okuloncesi.net/ upload/dosyalar/20111113/2300/2010-22.doc.

Aydın, Mustafa. "Değerler, İşlevleri ve Ahlak”, Eğitime Bakış 7/19 (2011): 39-45.

Biberci, Fatmanur. 2-7 Yaş Arası Çocuklarda Sevgi ve Merhamet Değerlerinin Hadisler Işı̆̆ııda Öğretimi. Yüksek Lisans Tezi, Selçuk Üniversitesi, 2010.

Cebeci, Aylin. İlköğretim Din Kültürü ve Ahlak Bilgisi Derslerinde Ahlaki Değgerlerin Eğitimi Ve Öğretimi. Yüksek Lisans Tezi, Uludağ Üniversitesi, 2005.

Çakmak, Ahmet. İlköğretim Din Kültürü ve Ahlak Bilgisi Derslerinde Adalet Değerinin Öğretimi. Yüksek Lisans Tezi, Atatürk Üniversitesi, 2013.

Çınar, Fatih. "Din Öğretiminde Değerler Eğitimi". Değerler Eğitimi. ed. Mevlüt Gündüz. 87-124. Ankara: Maya Akademi Yayınları, 2015.

35 Sancaklı, "Hadisler Çerçevesinde İsraf Olgusunun Analizi”, 45-86.

36 Aydın, "Okulda Çalışan Herkesin Görevi Olarak Değerler Eğitimi”.

37 Mustafa Köylü, "Kur'an'ın İnsanlığa Getirdiği Değerler ve Hedefler", On Dokuz Mayıs Üniversitesi Ilahiyat Fakültesi Dergisi 24-25 (2007): 71.

38 Sancaklı, "Hadisler" Çerçevesinde İsraf Olgusunun Analizi, 45-86. 
Gör, Fatih. Illkögrretim Din Kültürü ve Ahlak Bilgisi Ögrretim Programında Merhamet Değeri. Yüksek Lisans Tezi, Atatürk Üniversitesi, 2013.

Gücen, Ali. İlköğretim Din Kültürü ve Ahlak Bilgisi Derslerinde Bilimsellik Değerinin Öğretimi. Yüksek Lisans Tezi, Atatürk Üniversitesi, 2014.

Güleç, Yasemin. Adil Davranışlar Göstermede Din Eğitiminin Rolü. Doktora Tezi, Necmettin Erbakan Üniversitesi, 2014.

Gümüş, Çağrı. Ekmek İsrafını Önleme Konulu Sosyal Sorumluluk Kampanyasına İlişkin Akademisyen, Uzman ve Öğrenci Görüşleri. Doktora Tezi, Gazi Üniversitesi, 2015.

Hökelekli, Hayati. "Modern Eğitimde Yeni Bir Paradigma: Değerler Eğitimi”. Eğitime Bakış 18 (2010): 4-10.

Kaymakcan, Recep - Meydan, Hasan. “Demokratik Vatandaşlık ve Din Öğretimi: Yeni Yaklaşımlar ve Türkiye'de DKAB Dersleri Bağlamında Bir Değerlendirme”. İ.Ü. İlahiyat Fakültesi Dergisi 1/1 (2010): 29-53.

Kenan, Seyfi. “Modern Eğitimde Kaybolan Nokta: Değerler Eğitimi”. Kuram ve Uygulamada Eğitim Bilimleri 9/1(2009): 259-295.

Köylü, Mustafa. "Kur'an'ın İnsanlığa Getirdiği Değerler ve Hedefler". On Dokuz Mayıs Üniversitesi Illahiyat Fakültesi Dergisi 24-25 (2007): 65-88.

Köylü, Mustafa. Teoriden Pratiğe Değerler Eğitimi, Ankara: Nobel Yayınc1lık, 2016.

Mehmedoğlu, Ali Ulvi. “İlâhiyat Fakültesi Öğrencilerinin Değer Yönelimleri ve Dindarlık-Değer İlişkisi (M.Ü. İlâhiyat Fakültesi Örneği)”. M.Ü. İlâhiyat Fakültesi Dergisi 30 (2006): 133-167.

Mehmedoğlu, Yurdagül. Ahlaki ve Dini Gelişim \& Çocuğum Değerlerimizi Öğreniyor, İstanbul: Morpa Kültür Yayınları, 2004.

Nazıroğlu, Bayramali. "İlköğretim Din Kültürü ve Ahlak Bilgisi Dersi Öğretim Programında Vatandaşlık Eğitimi”. Din Bilimleri Akademik Araştırma Dergisi 11/ 2 (2011): 73-95.

Özden, Yüksel. Eğitimde Yeni Değerler, Ankara: PegemA Yayıncılık, 2005.

Sancaklı, Saffet. "Hadisler Çerçevesinde İsraf Olgusunun Analizi”, İ.Ü. İlahiyat Fakültesi Dergisi 4/1 (2013): 45-86.

Selçuk, Mualla. Çocuğun Eğitiminde Dini Motifler. Ankara: Türkiye Diyanet Vakfı Yayınları, 1991.

Şişman, Mehmet. Eğitim Bilimine Giriş. Ankara: PegemA Yayıncılık, 2007.

Ünal, Vehbi. Çevre Sorunları ve Dindarlık İlişkisi (Kayseri Örneği). Doktora Tezi, Selçuk Üniversitesi, 2010. 